ŁUKASZ DAWID DĄBROWSKI*

\title{
AgenCJe ANTYKorupcyjne na śWIEcie - PROBLEMY PRAWNE I ORGANIZACYJNE
}

\section{Uwagi wstępne}

Wyspecjalizowane instytucje (takie jak Policja, ABW, CBŚ, Straż Graniczna, a także służby skarbowe i celne) uczestniczące w egzekwowaniu prawa napotykają na wiele trudności w zapobieganiu, wykrywaniu i zaskarżaniu skomplikowanych przypadków korupcji. Tworzenie niezależnych agencji, biur lub komisji antykorupcyjnych staje się częstą praktyką podejmowaną przez rządy państw zmierzającą do kompleksowej walki z korupcją. W drodze modyfikacji, adaptacji istniejących organów lub powoływania nowych instytucji tworzy się organy, których zadaniem jest przeciwdziałanie korupcji. Tego rodzaju rozwiązania instytucjonalne wprowadziło wiele państw zarówno w Europie, Afryce, Azji i Ameryce.

Na potrzebę tworzenia agencji antykorupcyjnych zwrócono również uwagę na płaszczyźnie międzynarodowej. Konwencja Organizacji Państw Amerykańskich przeciw korupcji ${ }^{1}$, Konwencja Unii Afrykańskiej o zapobieganiu i zwalczaniu korupcji ${ }^{2}$, Protokół Wspólnoty Gospodarczej Państw Afryki Zachodniej przeciw korupcji ${ }^{3}$ Protokół Południowo Afrykańskiej

\footnotetext{
* Dr, adwokat, Kancelaria Adwokacka w Warszawie.

1 Inter-American Convention against Corruption, Caracas, 29 III 1996, (art. III ust. 9), www.oas.org/juridico/english/Treaties/b-58.html [dostęp: 13 czerwca 2015 r.].

2 Convention on Preventing and Combating Corruption (CPCC), Maputo, Mozambik11 VII 2003 (art. 5 ust. 3), www.african-union.org [dostęp: 13 czerwca 2015 r.].

${ }^{3}$ Protocol on the Fight Against Corruption, 21 XII 2001 (art. 5 pkt h), www.ecowas.int [dostęp: 13 czerwca 2015 r.].
} 
Wspólnoty Rozwoju przeciw korupcji ${ }^{4}$ Konwencja karnoprawna o korupcji Rady Europy ${ }^{5}$ oraz Konwencja ONZ przeciw korupcji ${ }^{6}$ zobowiązują strony do tworzenia odpowiedniego organu lub organów, których głównym celem będzie zapobieganie i zwalczanie korupcji. Zamieszczenie w konwencjach takiego postanowienia świadczy o efektywności tego rodzaju rozwiązań. Dowiodła tego także praktyka agencji działających w państwach azjatyckich. W Singapurze, Hong Kongu ${ }^{7}$ i Malezji udało się ograniczyć korupcję dzięki wprowadzeniu odpowiednich organów antykorupcyjnych. W celu wypełnienia międzynarodowych zobowiązań ${ }^{8}$ również w Polsce utworzono antykorupcyjną agencję pod nazwą Centralne Biuro Antykorupcyjne.

W opracowaniu dokonano przeglądu rozwiązań instytucjonalnych przyjmowanych w różnych państwach. Przedstawienie uregulowań prawnych, a także charakterystyka podejmowanych na ich podstawie działań umożliwia dokonanie oceny ich skuteczności na płaszczyźnie krajowej i międzynarodowej. W tym celu posłużono się metodą prawnoporównawczą. Szczególną uwagę zwrócono na wiodące w świecie agencje antykorupcyjne (w Hong Kongu, Singapurze i Australii) oraz na te państwa, które według indeksu percepcji korupcji (Corruption Perceptron Index $-\mathrm{CPI}^{9}$ ) szacującego ogólny poziom korupcji w państwie nie osiągnęły

${ }^{4}$ Protocol against Corruption, Blantyre, Malawi, 14 VIII 2001 (art. 4 ust. 1 pkt g), www. sadc.int [dostęp: 13 czerwca 2015 r.].

${ }^{5}$ Karnoprawna Konwencja o korupcji, Strasburg, 27 I 1999, Dz. U. z 2005 r., Nr 29, poz. 249 (art. 20).

${ }^{6}$ Konwencja Narodów Zjednoczonych przeciwko korupcji, 31 X 2003 (art. 6 i art. 36)..

${ }^{7} \mathrm{~W}$ latach 40 i 50 XX wieku korupcja była bardzo rozpowszechniona w Singapurze, szczególnie wśród urzędników państwowych i w biznesie. W latach 60 i 70 XX wieku korupcja rozpowszechniła się w Hong Kongu zarówno w sektorze publicznym, jak i w biznesie. Skorumpowana była policja, służby celne, służby imigracyjne, straż pożarna i więziennictwo.

${ }^{8}$ Konwencja karnoprawna Rady Europy o korupcji, weszła w życie 1.07.2002 r., ratyfikowana przez Polskę 11.12.2002 r., w stosunku do Polski weszła w życie 1.04.2003 r., Konwencja ONZ przeciw korupcji, weszła w życie 14.12.2005 r.,ratyfikowana przez Polskę 15.09.2006 r., w stosunku do Polski weszła w życie 15.10.2006 r.

9 Transparency International Corruption Perceptions Index 2007: Results, www. transparency.org/research/cpi/cpi_2007 [dostęp: 14 czerwca 2015 r.], w grupie badanych znalazło się 180 państw, każdemu z państw przyznano punkty od 0 (wysoka korupcja) do 10 (brak korupcji), Transparency International Corruption Perceptions Index 2014: Results, www.transparency.org/cpi2014/results [dostęp: 14 czerwca 2015 r.], w grupie badanych znalazło się 175 państw, każdemu z państw przyznano punkty od 0 (wysoka korupcja) do 100 (brak korupcji). 
najwyższych wyników, by wykazać, że instytucje takie per se nie likwidują korupcji.

W opracowaniu wykorzystano różne dokumenty i sprawozdania instytucji zajmujących się zagadnieniem korupcji, a także artykuły zamieszczone w czasopismach prawniczych. Źródłem informacji były również zasoby stron internetowych krajowych antykorupcyjnych organizacji.

\section{Modele agencji - organizacja}

John R. Heilbrunn ${ }^{10}$ wyróżnił cztery modele antykorupcyjnych agencji ze względu na ich funkcje i sposób usytuowania w aparacie państwa: 1) model uniwersalny (universal model) z funkcją dochodzeniowa, prewencyjną i komunikacyjna, 2) model dochodzeniowy (investigative model) z małą i scentralizowaną komisją dochodzeniową 3) model parlamentarny (parliamentary model) obejmujący obowiązek składania raportów komisjom parlamentarnym, jest niezależny od władzy wykonawczej i sądowniczej, 4) model wieloagencyjny (multi-agency model), na który składa się wiele pojedynczych instytucji łącznie tworzących sieć agencji walczących $\mathrm{z}$ korupcją. Podział ten został przyjęty w literaturze przedmiotu ${ }^{11}$.

\subsection{Model uniwersalny}

Model uniwersalny jest charakterystyczny dla Niezależnej Komisji Przeciw Korupcji (Independent Commission Against Corruption - ICAC) działającej od 1974 r. w Hong Kongu ${ }^{12}$. Odnosi ona największe sukcesy spośród wszystkich powołanych do tej pory agencji. ICAC zatrudnia, na podstawie umów cywilnoprawnych, ok. 1200 pracowników. Funkcjona-

10 J. R. Heilbrunn, Anti-Corruption Commissions: Panacea or Real Medicine to Fight Corruption?, World Bank Institute 2004, s. 3.

${ }^{11}$ J.S.T. Quah, Anti-Corruption Agencies in Four Asian Countries: A Comparative Analysis, "International Public Management Review" 2007, vol. 8, nr 2; J.J. Coonjohn, A primer on Models and Strategies 2011 for Anti-Corruption Agencies. Preparing Afghanistan for Anti-Corruption Reform, www.jjcoonjohn.com [dostęp: 16 czerwca 2015 r.].

${ }_{12}$ Szerzej na temat agencji na stronie: www.icac.org.hk/eng/main [dostęp: 15 czerwca 2015 r.]. Hong Kong w 2007 r. uzyskał 8.3 pkt CPI zajmując 14 miejsce, w 2014 r. uzyskał 74 pkt zajmując 17 miejsce. 
riusze wyłaniani są w drodze konkursów i nie mogą wejść w skład rządu Hong Kongu po opuszczeniu agencji. Pracę w ICAC cechuje stabilność zatrudnienia, co wpływa na rozwój specjalizacji i wysoki poziom merytoryczny ekspertów ${ }^{13}$. ICAC w Hong Kongu dzieli się na trzy departamenty: dochodzeniowy, prewencyjny i kontaktów społecznych ${ }^{14}$. Największy spośród departamentów jest Departament Operacyjny przeprowadzający dochodzenia w przypadku podejrzenia o czyny korupcyjne. Prawie $1 / 3$ budżetu agencji przeznaczona jest na działalność tego departamentu. Departament Prewencji prowadzi studia nad korupcja, przeprowadza seminaria i pomaga organizacjom publicznym i prywatnym $\mathrm{w}$ ustaleniu strategii redukcji korupcji. Departament ten dokonuje regularnego przeglądu prawa i rewizji przepisów na podstawie prowadzonych przez siebie badań ${ }^{15}$. Departament Kontaktów Społecznych informuje opinię społeczną o uregulowaniach prawnych, buduje świadomość społeczną dotyczącą zagrożeń związanych z korupcja, przeprowadza kampanie społeczne, telewizyjne, przygotowuje filmy dokumentalne. ICAC odpowiada hierarchicznie przed Szefem Egzekutywy Specjalnego Regionu Administracyjnego Hong Kongu, dyrektorem ICAC oraz trzema komitetami nadzorczymi $^{16}$.

Podobną strukturę ma powołana 1 października 1967 r. Anty-Korupcyjna Agencja (Anti-Corruption Agency) w Malezji, przekształcona w 2009 r. w Malezyjską Anty-Korupcyjną Komisje (Malaysian Anti-Corruption Commision - MACC) ${ }^{17}$, usytuowana w gabinecie premiera. Personel agencji początkowo stanowili policjanci, obecnie rekrutuje się on spośród członków służby cywilnej, tworząc oddzielną administrację. Dyrektor Generalny MACC mianowany jest przez króla po uzyskaniu opinii premiera i akceptacji parlamentu. Urząd składa się z 12 wydziałów kierowanych przez dyrektorów, a także Publicznego Biura Skarg (Complaints Committee), do którego można składać zażalenia na personel agencji.

${ }^{13}$ J. R. Heilbrunn, Anti-Corruption Commissions..., s. 4

${ }_{14}$ J. Pope, F. Vogel, Making Anticorruption Agencies More Effective, „Finance\&Development" 2000, vol. 37, nr 2, s. 8.

${ }^{15}$ J. S. T. Quah, Defying institutional Failure: learning from the experiences of anti-corruption agencies in four Asian countries, "Crime, Law \& Social Change” 2010, nr 53, s. 31. s. 104

16 J. Pope, Confronting corruption: the elements of a national integrity system, Berlin 2000,

17 Szerzej na temat agencji na stronie: www.sprm.gov.my [dostęp: 15 czerwca 2015 r.], Malezja w 2007 r. uzyskała 5.1 pkt CPI zajmując 43 miejsce, w 2014 r. uzyskała 52 pkt zajmując 50 miejsce. 
W 2002 r. ustanowiono Komisję Zwalczania Korupcji (Commission for Eradication of Corruption - CEC) w Indonezji ${ }^{18}$. Komisją kieruje 5 komisarzy działających w charakterze urzędników rządowych. Ich wyboru dokonuje parlament z listy przedstawionej przez prezydenta. Listę kandydatów przygotowuje specjalny komitet wyznaczony przez rząd. Komisja składa się z 4 wydziałów oraz sekretariatu. Ponadto w Indonezji utworzono Specjalny Sąd do spraw Korupcji (Special Court of Corruption) składający się z 5 sędziów: 2 sędziów wyznaczonych przez Prezesa Sądu Najwyższego oraz 3 sędziów ad hoc wyznaczonych przez Prezydenta po konsultacji z Prezesem Sądu Najwyższego. Podobne sądy zostały utworzone na Filipinach, w Pakistanie, Ugandzie, Indiach i Malezji ${ }^{19}$.

Model uniwersalny przyjęto także: w Tanzanii ${ }^{20}$, gdzie w 1991 r. utworzono Biuro Prewencji Korupcji (Prevention of Corruption Bureau), przekształcone w 2007 r. w Biuro Prewencji i Zwalczania Korupcji (Prevention and Combating of Corruption Bureau - PCCB); w Botswanie ${ }^{21}$, gdzie w 1994 r. powołano Dyrektoriat do spraw Korupcji i Przestępczości Ekonomicznej (Directorate on Corruption and Economic Crime - DCEC), usytuowany w urzędzie prezydenta; w Malawi, gdzie w 1995 r. powołano Biuro Antykorupcyjne (Anti-Corruption Bureau - ACB) odpowiedzialne przed ministrem sprawiedliwości ${ }^{22}$; w Korei ${ }^{23}$, gdzie w 2002 r. powołano Koreańską

18 Szerzej na temat agencji na stronie: www.kpk.go.id [dostęp: 15 czerwca 2015 r.], Indonezja w 2007 r. uzyskała 2.3 pkt CPI zajmując 143 miejsce, w 2014 r. uzyskała 34 pkt zajmując 107 miejsce.

19 S. A. Schütte, S. Butt, Assessing judical performance In Indonesia: the court for corruption crimes, "Crime, Law \& Social Change” 2014, vol. 62, nr 5, s. 605. Szerzej zob. A. Harding, P. Nicholson, New Courts in Asia, "Asian Journal of Criminology" 2012, vol. 7, nr 2, s. 197199.

20 I. Carr, Corruption, the Southern Africa Development Community Anti-corruption Protocol and the principal-agent-client model, "International Journal of Law in Context" 2009, nr (5) 2, s. 166; A. Doig, D. Watt, R. Williams, Measuring 'success' in five African Anti-Corruption Commissions - the casus of Ghana, Malawi, Tanzania, Uganda \& Zambia, U4 Reports 2005, s. 81; szerzej na temat agencji na stronie: www.pccb.go.tz [dostęp: 15 czerwca 2015 r.], Tanzania w 2007 r. uzyskała 3.2 pkt CPI zajmując 94 miejsce, w 2014 r. uzyskała 31 pkt zajmując 119 miejsce.

${ }^{21}$ Institutional Arrangements to Combat Corruption. A Comparative Study, United Nations Development Programme 2005, s. 35; szerzej na temat agencji na stronie: www.gov.bw [dostęp: 15 czerwca 2015 r.], Botswana w 2007 r. uzyskała 5.4 pkt CPI zajmując 38 miejsce, w 2014 r. uzyskała 63 pkt zajmując 31 miejsce.

22 A. Doig, D. Watt, R. Williams, Measuring 'success'..., s. 61; Malawi w 2007 r. uzyskał 2.7 pkt CPI zajmując 69 miejsce, w 2014 r. uzyskała 33 pkt zajmując 110 miejsce.

${ }^{23}$ Szerzej na temat agencji na stronie: www.kicac.go.kr [dostęp: 15 czerwca 2015 r.], Korea w 2007 r. uzyskała 5.1 pkt CPI zajmując 43 miejsce, w 2014 r. uzyskała 55 pkt zajmując 43 miejsce. 
Niezależną Komisję Przeciw Korupcji (Korea Independent Commission Against Corruption - KICAC) ${ }^{24}$; na Łotwie ${ }^{25}$, gdzie w 2003 r. utworzono Biuro Zwalczania i Zapobiegania Korupcji (Corruption Prevention and Combating Bureau - CPCB).

\subsection{Model dochodzeniowy}

Model dochodzeniowy jest charakterystyczny dla Biura ds. Ścigania Praktyk Korupcyjnych (Corrupt Practices Investigation Bereau - CPIB), założonego w 1952 r. w Singapurze ${ }^{26}$. Singapurskie Biuro ma niewielki skład, poddane jest wpływom policji ${ }^{27}$ i koncentruje się głównie na funkcji dochodzeniowej. Podobnie jak agencja w Hong Kongu jest zorganizowane hierarchicznie. Biuro usytuowane jest w systemie władzy wykonawczej ${ }^{28}$. Dyrektor powoływany jest przez prezydenta po rekomendacji gabinetu lub ministra działającego z umocowania gabinetu. Prezydent mianuje także zastępcę dyrektora oraz tylu asystentów i specjalnych śledczych, ilu jest potrzebnych ${ }^{29}$. Dyrektor odpowiada przed premierem, zaś raporty przesyłane są przez oddziały agencji prezydentowi. Pomimo wąskich uprawnień i niewielkiej liczby personelu, Biuro wiele dochodzeń zakończyło udowodnieniem winy.

Ustawą z dnia 9 czerwca 2006 r. o Centralnym Biurze Antykorupcyjnym $^{30}$ powołano w Polsce Centralne Biuro Antykorupcyjne (CBA). CBA jest formacją specjalistyczną o charakterze policyjnym i analityczno-informacyjnym. CBA ma status służby specjalnej. W sferze organizacyjnej Biuro jest urzędem administracji rządowej, kierowanym przez Szefa CBA

${ }^{24}$ J. S. T. Quah, Defying institutional Failure..., s. 36.

${ }^{25}$ Szerzej na temat agencji na stronie: www.knab.gov.lv/en [dostęp: 15 czerwca 2015 r.], Łotwa w 2007 r. uzyskała 4.8 pkt CPI zajmując 51 miejsce, w 2014 r. uzyskała 55 pkt zajmując 42 miejsce.

${ }^{26}$ Szerzej na temat agencji na stronie: www.cpib.gov.sg [dostęp: 15 czerwca 2015 r.], Singapur w 2007 r. uzyskał 9.3 pkt CPI zajmując 4 miejsce, w 2014 r. uzyskał 84 pkt zajmując 7 miejsce.

${ }^{27}$ J. R. Heilbrunn, Anti-Corruption Commissions..., s. 6.

${ }^{28}$ J. R. Heilbrunn, Anti-Corruption Commissions..., s. 7.

29 J. S. T. Quah, Defying institutional Failure..., s. 27.

${ }^{30}$ Ustawa z dnia 9 czerwca 2006 r., o Centralnym Biurze Antykorupcyjnym, t. j. Dz. U. z 2016 r. poz. 1310 (dalej jako: ustawa o CBA); szerzej na temat agencji na stronie: www. cba.gov.pl [dostęp: 15 czerwca 2015 r.], Polska w 2007 r. uzyskała 4.2 pkt CPI zajmując 62 miejsce, w 2014 r. uzyskała 61 pkt zajmując 35 miejsce. 
nadzorowanego przez prezesa Rady Ministrów. W myśl art. 6 ustawy o CBA: „Szefa CBA powołuje i odwołuje, na czteroletnią kadencję, Prezes Rady Ministrów, po zasięgnięciu opinii Prezydenta Rzeczypospolitej Polskiej, Kolegium do Spraw Służb Specjalnych oraz sejmowej komisji do spraw służb specjalnych". W skład CBA wchodzi 12 jednostek organizacyjnych, m.in. Zarządy: Operacyjno-Śledczy, Postępowań Kontrolnych, Analiz i Ewidencji oraz Techniki Operacyjnej, Gabinet Szefa, Departamenty: Ochrony, Kadr i Szkolenia, Finansów oraz Logistyki, a także Samodzielny Wydział Prawny, Samodzielny Wydział Inspekcji oraz Zespół Audytu Wewnętrznego. Służbę w CBA pełnią funkcjonariusze mający taki sam status jak funkcjonariusze Agencji Bezpieczeństwa Wewnętrznego, Policji i Straży Granicznej. CBA zatrudnia teleinformatyków i elektroników, prawników, finansistów, analityków i ekonomistów.

Model dochodzeniowy przyjęto także w Holandii, gdzie głównym zadaniem Państwowej Służby Śledczej (Rijksrecherche) jest prowadzenie dochodzeń i zbieranie materiałów dowodowych ${ }^{31}$.

\subsection{Model parlamentarny}

Model parlamentarny jest charakterystyczny dla Niezależnej Komisji Przeciw Korupcji (Independent Commission Against Corruption - ICAC) działającej w Nowej Południowej Walii (Australia) ${ }^{32}$ od 1988 r. Komisja jest zorganizowana hierarchicznie i składa się z komisarza, asystenta komisarza i dyrektorów czterech jednostek operacyjnych. Jednostka Dochodzeniowa przeprowadza dochodzenia w sprawie domniemanych przestępstw korupcyjnych. Jednostka Prawna jest łącznikiem z parlamentarnymi komisjami kontrolnymi, prowadzi doradztwo prawne, nadzoruje przeprowadzane dochodzenia oraz przekazuje informacje do Komitetu Parlamentarnego. Jednostka Prewencji, Edukacji i Badań działa w zakresie prewencji, edukacji, prowadzenia badań i kontaktów z mediami. Jednost-

${ }^{31}$ Uzasadnienie projektu ustawy o Centralnym Biurze Antykorupcyjnym, Druk Sejmu RP V kadencji, nr druku 275 z dnia 23 stycznia 2006 r., dostępne na stronie: www.orka. sejm.gov.pl [dostęp: 9 września 2014 r.], Holandia w 2007 r. uzyskała 9.0 pkt CPI zajmując 7 miejsce, w 2014 r. uzyskała 83 pkt zajmując 8 miejsce.

${ }^{32}$ Szerzej na temat agencji na stronie: www.icac.nsw.gov.au [dostęp: 15 czerwca 2015 r.], Australia w 2007 r. uzyskała 8.6 pkt CPI zajmując 11 miejsce, w 2014 r. uzyskała 80 pkt zajmując 11 miejsce. 
ka Usług Przedsiębiorczości i Handlu podejmuje działania antykorupcyjne $\mathrm{w}$ sektorze prywatnym ${ }^{33}$. Dyrektor mianowany jest przez gubernatora na 5 lat i nie może być powtórnie wybrany. Wewnętrzną koordynację zapewnia Zarządzająca Grupa Prewencyjna, nadzorująca działania prewencyjne, edukacyjne, badania, zapewniająca koordynację w pozostałym zakresie oraz Zarządzająca Grupa Dochodzeniowa, spełniająca rolę doradczą i nadzorująca prowadzone postępowania. ICAC może prowadzić sprawy dotyczące sektora prywatnego, jeśli mają związek z sektorem publicznym.

Na Litwie ${ }^{34}$ w 1997 r. powołano Specjalną Służbę Dochodzeniową (Special Investigation Service - SIS). Dyrektora SIS mianuje prezydent za zgodą Senatu, a jego zastępców Prezydent po konsultacji z dyrektorem. SIS jest zobowiązany co najmniej 2 razy do roku do składania raportów z działalności prezydentowi oraz marszałkowi senatu. SIS podzielona jest na wiele wydziałów i departamentów ${ }^{35}$.

W Tajlandiii ${ }^{36}$ w 1999 r. utworzono Państwową Komisję ds. Walki z Korupcją (National Anti-Corruption Commission - NACC). Jest to niezależna komisja ponosząca odpowiedzialność przed Senatem. Składa się z 9 komisarzy (w tym Prezydenta) powoływanych na 9 letnią kadencję, bez prawa powtórnego wyboru. Komisarzy wybiera senat z listy 18 kandydatów rekomendowanych przez komisję składającą się z 15 obywateli ${ }^{37}$. Organizacyjne komisja jest podzielone na 4 wydziały.

Odpowiedzialność przed parlamentem organu zwalczającego korupcję przewidziano również w Zambii, gdzie w 1982 r. powołano Komisję Antykorupcyjną (Anticorruption Commission) ${ }^{38}$ oraz w Ugan-

${ }_{33}$ J. R. Heilbrunn, Anti-Corruption Commissions..., s. 9.

34 Szerzej na temat agencji na stronie: www.stt.lt/?lang=en [dostęp: 15 czerwca 2015 r.], Litwa w 2007 r. uzyskała 4.8 pkt CPI zajmując 51 miejsce, w 2014 r. uzyskała 58 pkt zajmując 39 miejsce.

${ }^{35}$ Institutional Arrangements..., s. 58.

36 Osobą nominowaną na komisarza może być jedynie minister, sędzia sądu konstytucyjnego, niezależny komisarz, Rzecznik Praw Obywatelskich, członek Narodowej Komisji Praw Człowieka, członek Państwowej Komisji Audytu, dyrektor generalny (bądź jego odpowiednik) lub profesor uniwersytecki. Szerzej na temat agencji na stronie: www.nacc. go.th [dostęp: 15 czerwca 2015 r.], Tajlandia w 2007 r. uzyskała 3.3 pkt CPI zajmując 84 miejsce, w 2014 r. uzyskała 38 pkt zajmując 85 miejsce.

37 J. S. T. Quah, Defying institutional Failure..., s. 36.

38 Szerzej na temat agencji zob.: Instytucje Antykorupcyjne w Wybranych Państwach Świata, Centralne Biuro Antykorupcyjne, Warszawa 2010, s. 72 i n., tekst dostępny na stronie: www.cba.gov.pl [dostęp: 9 września 2014 r.]. 
dzie, gdzie w 1995 r. powołano Inspektorat Rządowy (Inspectorate of Government) $)^{39}$.

\subsection{Model wieloagencyjny}

Model wieloagencyjny zastosowano m. in. w Stanach Zjednoczonych, RPA, Bułgarii i Nigerii. W Urzędzie ds. Etyki Stanów Zjednoczonych (United States Office of Government Ethics - OGE) działa wiele agencji dochodzeniowych, prewencyjnych i edukacyjnych. Urząd, będąc jednym z komponentów multiagencyjnego modelu walki z korupcją, współdziała z różnymi urzędami rządowymi, a także agencjami usytuowanymi w Departamencie Sprawiedliwości oraz z policją federalną. OEG odpowiada przed Prezydentem i Kongresem. Nie ma funkcji dochodzeniowych, ale odgrywa dużą rolę prewencyjną i edukacyjną ${ }^{40}$.

W Republice Południowej Afryki funkcje dochodzeniowe i oskarżycielskie wykonuje Krajowa Agencja Prokuratury (National Prosecuting Agency of South Africa - NPA), Specjalna Jednostka Dochodzeniowa oraz Policja. Prewencją i wykrywaniem korupcji zajmuje się Urząd Audytu, Urząd Ochrony, Urząd Skarbowy oraz Komisja Usług Publicznych. Krajowa Agencja Prokuratury (NPA) jest instytucją wspierającą wysiłki państwa w zwalczaniu korupcji i przestępczości zorganizowanej. Dwie jednostki NPA odgrywają kluczową rolę w walce z korupcją: Oddział do zadań specjalnych, znany jako "Skorpion” (the Scorpions) oraz Jednostka Konfiskaty Mienia. Zadania wspierające, koordynujące i integrujące działania antykorupcyjne sprawuje Antykorupcyjny Komitet Koordynujący ${ }^{41}$.

W Bułgarii nie ma jednej wyspecjalizowanej agencji zajmującej się zapobieganiem i zwalczaniem korupcji. Wiele jednostek, wydziałów, departamentów i agencji zostało utworzonych w różnych ministerstwach, wymiarze sprawiedliwości i policji. Koordynacyjną i konsolidacyjną funkcję sprawuje Komisja Koordynująca Działania Antykorupcyjne (Commission

39 A. Doig, D. Watt, R. Williams, Measuring 'success'..., s. 73, 80; Zambia w 2007 r. uzyskał 2.6 pkt CPI zajmując 123 miejsce, w 2014 r. uzyskała 38 pkt zajmując 85 miejsce; Uganda w 2007 r. uzyskał 2.8 pkt CPI zajmując 111 miejsce, w 2014 r. uzyskała 26 pkt zajmując 142 miejsce; szerzej na temat instytucji zob.: Instytucje Antykorupcyjne..., s. 70.

40 J. R. Heilbrunn, Anti-Corruption Commissions..., s. 10. Stany Zjednoczone w 2007 r. uzyskały 7.2 pkt CPI zajmując 20 miejsce, w 2014 r. uzyskały 74 pkt zajmując 17 miejsce.

${ }^{41}$ Institutional Arrangements..., s. 82; Republika Południowej Afryki w 2007 r. uzyskała 5.1 pkt CPI zajmując 43 miejsce, w 2014 r. uzyskała 44 pkt zajmując 67 miejsce. 
for Coordinating Actions Against Corruption) założona w 2002 r. Jest to wewnątrzministerialna komisja składająca się z przedstawicieli Ministerstwa Finansów, Ministerstwa Spraw Wewnętrznych, Ministerstwa Sprawiedliwości oraz Krajowego Biura Audytu. Komisja nie ma funkcji dochodzeniowych. W 2002 r. Zgromadzenie Narodowe powołało Stałą Komisję Parlamentarną składającą się z 24 członków, której zadaniem było dostosowanie prawa krajowego do standardów europejskich ${ }^{42}$.

W Nigerii ${ }^{33}$ funkcję koordynującą pełni utworzona w 2002 r. Niezależna Komisja do spraw Praktyk Korupcyjnych i innych Przestępstw (Independent Corrupt Practices and Other Related Offences Commission). Składa się ona z przewodniczącego i 12 członków mianowanych przez Prezydenta po zatwierdzeniu przez Senat. Każdy z nich może być odwołany przez prezydenta na żądanie 2/3 Senatu.

W Ghanie dwie instytucje zajmują się przestępczością korupcyjną: Komisja Praw Człowieka i Sprawiedliwości (Commission for Human Rights and Administrative Justice) utworzona w 1993 r. oraz Urząd ds. ścigania poważnych przestępstw finansowych (Serious Fraud Office), utworzony w 1993 r. pełniący funkcje dochodzeniowe ${ }^{44}$.

W Indiach uregulowania antykorupcyjne są wdrażane przez wiele instytucji m.in. Centralne Biuro Dochodzeniowe (Central Bureau of Investigation) i państwowe biura antykorupcyjne (state anticorruption bureaus) ${ }^{45}$. Na Filipinach sprawami przestrzegania siedmiu antykorupcyjnych ustaw zajmuje się 14 antykorupcyjnych agencji założonych od $1950 \mathrm{r}$. W Chinach trzy agencje uczestniczą we wdrażaniu przepisów antykorupcyjnych: Najwyższa Prokuratura Ludowa (Supreme People's Procuratorate) z 1978 r.

42 Institutional Arrangements..., s. 39 i n; Bułgaria w 2007 r. uzyskała 4.1 pkt CPI zajmując 64 miejsce, w 2014 r. uzyskała 43 pkt zajmując 69 miejsce.

43 Postawiono duże wymagania co do składu osobowego komisji. Przewodniczącym może być sędzia lub osoba spełniająca warunki do objęcia urzędu sędziego, pozostali członkowie zaś: 2 emerytowanych członków policji (w randze nie niższej niż komisarz), 2 prawników (z co najmniej 10 letnią praktyką w zawodzie), 2 emerytowanych urzędników publicznych (w randze co najmniej dyrektorów), 2 kobiety, 2 członków w wieku 21 a 30 lat (w czasie mianowania). Szerzej na temat agencji na stronie: http://www.icpc.gov.ng [dostęp: 15 czerwca 2015 r.] Nigeria w 2007 r. uzyskała 2.2 pkt CPI zajmując 147 miejsce, w 2014 r. uzyskała 35 pkt zajmując 103 miejsce.

${ }^{44}$ A. Doig, D. Watt, R. Williams, Measuring 'success'..., s. 56; Ghana w 2007 r. uzyskał 3.7 pkt CPI zajmując 69 miejsce, w 2014 r. uzyskała 48 pkt zajmując 61 miejsce.

45 J. Jones, India versus the United Nations: The Central Vigilance Commission Act Does Not Satisfy The U.N. Convention Against Corruption, "Emory International Law Review" 2008, nr 22, s. 823. 
walcząca z korupcją w wymiarze sprawiedliwości, Centralny Komitet Nadzoru Dyscyplinarnego (Central Disciplinary Inspection Committee) powołany do kontroli korupcji wśród członków Chińskiej Partii Komunistycznej oraz Ministerstwo Kontroli (Ministry of Supervision) z 1986 r. do walki z korupcją w administracji państwowej. W świetle badań CPI komunistyczne Chiny są bardziej efektywne w walce z tym zjawiskiem niż demokratyczne Indie lub Filipiny ${ }^{46}$.

\section{Strategia działania - mandat agencji}

Mandat poszczególnych agencji uzależniony jest m. in. od celów realizowanych przez agencje oraz uprawnień przysługujących innym organom (policji i prokuraturze). Większość agencji podejmuje działania w trzech płaszczyznach: dochodzeniowej - kluczowej dla instytucji zwalczającej zachowania przestępcze, prewencyjnej - zmierzającej do wyeliminowania możliwości sprzyjających zachowaniom korupcyjnym, zarówno w sektorze publicznym, jak i prywatnym oraz analitycznej - dopełniającej całość strategii antykorupcyjnej. Połączenie tych trzech rodzajów uprawnień pozwala funkcjonariuszom agencji na osiąganie wysokiej skuteczności działań.

\subsection{Uprawnienia śledczo-oskarżycielskie}

Agencje wyposażone w mandat dochodzeniowo-śledczy z reguły są zobowiązane do prowadzenia postępowań bez względu na sposób uzyskiwania wiadomości o przestępstwie: na skutek zawiadomienia obywatelskiego (Botswana, także anonimowego - Hong Kong, Malezja, Tajlandia), ze źródeł własnych lub innych instytucji państwowych (np. za pośrednictwem parlamentu w Nowej Południowej Walii). Wszczęcie postępowania jest uzależnione od dostatecznego uzasadnienia podejrzenia popełnienia

${ }^{46}$ J. S. T. Quah, Curbing Asian Corruption..., s. 178; Indie w 2007 r. uzyskały 3.5 pkt CPI zajmując 72 miejsce, w 2014 r. uzyskały 38 pkt zajmując 85 miejsce; Filipiny w 2007 r. uzyskały 2.5 pkt CPI zajmując 131 miejsce, w 2014 r. uzyskały 38 pkt zajmując 85 miejsce; Chiny w 2007 r. uzyskały 3.5 pkt CPI zajmując 72 miejsce, w 2014 r. uzyskały 36 pkt zajmując 100 miejsce. 
przestępstwa. Łatwość zgłaszania zachowań korupcyjnych w Hong Kongu i Korei (dzięki Corruption Report Center) sprawia, że wobec dużej liczby zawiadomień prowadzonych jest wiele postępowań. Nigeryjskie skomplikowane procedury składania skarg wpływają na niski stopień współpracy społecznej. Jedną z przeszkód społecznego zaangażowania jest także strach przed represją. Istnieje zatem potrzeba wypracowania skutecznych uregulowań prawnych, zapewniających ochronę zgłaszającym przestępstwa, świadkom i osobom współpracującym z wymiarem sprawiedliwości (jak np. w Hong Kongu, Korei, Indonezji) - bowiem tam, gdzie system ochrony jest skuteczny, liczba skarg anonimowych jest niższa.

Główne uprawnienia agencji nie różnią się od uprawnień przysługujących innym jednostkom dochodzeniowym, np. policji lub prokuraturze. W zależności od państwa agencje mają różny zakres instrumentów prawnych. Do najważniejszych należą: prawo żądania od osób i instytucji potrzebnych informacji i dokumentów (m.in. Australia, Botswana, Indonezja, Łotwa, Polska), dokonywanie przeszukań osób i mienia (m.in. Australia za zgodą sędziego lub komisarza agencji, Malezja, Nigeria, Tanzania, Polska), kontrolowanie bagażu, zatrzymywanie pojazdów (Polska), kontrolowanie rachunków bankowych (m.in. Hong Kong, Polska), wzywanie świadków (m.in. Łotwa, Malezja, Tajlandia) łącznie z publicznymi przesłuchaniami (Australia), audyt prywatnych środków, zatrzymywanie paszportów (m.in. Botswana), wydawanie zakazów opuszczania kraju, stosowanie nadzoru, stosowanie podsłuchu (m.in. Australia, Polska), kontrola korespondencji (Litwa, Polska), legitymowanie osób (Polska), stosowanie zatrzymania i aresztu (Malezja, Nigeria, Singapur, Tanzania, Botswana po autoryzacji dyrektora), użycie płatnych informatorów (Malezja), kontrola rzetelności i prawdziwości oświadczeń majątkowych (Łotwa, Tajlandia, Polska) oraz prowadzenie postępowań dotyczących osób utrzymujących standard życia nieadekwatny do dochodów uzyskiwanych ze znanych źródeł (Botswana), a także kontrola operacyjna i zakup kontrolowany $(\text { Polska })^{47}$. Polskie CBA prowadzi ponadto czynności kontrolne polegające na sprawdzaniu przestrzegania przepisów przez osoby pełniące funkcje publiczne oraz przedsiębiorców. Często do wykonania tych uprawnień wymagana jest pisemna zgoda prokuratora (Malezja, Singapur), sędziego (Tajlandia) lub szefa agencji (Nigeria, Tanzania). Stosowanie np. kontroli operacyjnej i zakupu kontrolowanego przez funkcjonariuszy polskiego

\footnotetext{
${ }^{47}$ Institutional Arrangements..., s. 53 i n.; art. 17 i 19 ustawy o CBA.
} 
CBA uzależnione jest, odpowiednio, od zgody Sądu Okręgowego w Warszawie oraz Prokuratora Generalnego.

W zakresie działań operacyjno-rozpoznawczych interesującą propozycję przedstawił były komisarz ICAC w Hong Kongu. Zaproponował on dokonywanie nagrań wideo wszystkich przesłuchań osób podejrzanych, $\mathrm{w}$ trzech kopiach, z przeznaczeniem jednej kopii dla podejrzanego, drugiej dla sądu, trzeciej dla agencji. Możliwość zapoznania się podejrzanego z takim materiałem i późniejsze dopuszczenie nagrań z przesłuchania jako dowodu przed sądem powoduje, iż wiele osób przyznaje się do winy bez prób odwoływania lub zmiany zeznań. Powoduje to oszczędność środków i czasu sądu ${ }^{48}$. W ICAC w Australii wprowadzono możliwość przeprowadzania jawnych przesłuchań (public hearings), polegających na przesłuchiwaniu świadków w celu uzyskania dowodów. Dowody te nie mogą być wykorzystane przeciw nim w postępowaniu karnym, ale przesłuchania umożliwiły zapoznanie się społeczeństwa z przestępczymi praktykami ${ }^{49}$. Z drugiej strony w Hong Kongu wprowadzono zakaz ujawnienia personaliów osób podejrzanych, dopóki nie zostanie wydany nakaz przeszukania lub aresztowania. Naruszenie tego zakazu przez członków personelu ICAC pociąga za sobą poważne skutki, łącznie z odpowiedzialnością karną ${ }^{50}$.

Nie wszystkie agencje wyposażone zostały w mandat oskarżycielski. Funkcja ta zwykle pozostawiona jest organom prokuratury. Po zakończonym postępowaniu dochodzeniowym, jeśli istnieją podstawy do oskarżenia, sprawa przekazywana jest prokuraturze (np.: Australia, Botswana, Bułgaria, Hong Kong, Litwa, Malezja, Singapur, Ghana). Poza tą ogólną regułą istnieją pewne wyjątki. W Botswanie Prokurator Generalny jest umocowany do prowadzenia wszelkich postępowań sądowych, łącznie z przestępstwami korupcyjnymi, jednak z uwagi na duże obciążenie urzędu prokuratora, faktycznie agencja zajmuje jego miejsce. W Tanzanii Sekcja Oskarżycielska PCCB może prowadzić postępowania sądowe po uzyskaniu akceptacji Dyrektora Prokuratury. Sekcja ta współpracuje ściśle z policją i prokuraturą. W Tajlandii NACC działa jak oskarżyciel w trzech przypadkach: sprawach prowadzonych przed Sądem Konstytucyjnym, gdy oskarżonym jest Prokurator Generalny oraz gdy Prokurator Gene-

\footnotetext{
48 The Global Programme against Corruption..., s. 183 i n.

49 J. Pope, Confronting corruption..., s. 103.

50 The Global Programme against Corruption..., s. $185 \mathrm{i}$.
} 
ralny odmówi prowadzenia postępowania przed sądem. Uprawniania w zakresie oskarżania mają także agencje w Malawi, Ugandzie i Zambii ${ }^{51}$.

W państwach, gdzie policja i prokuratura są skorumpowane, mandat oskarżycielski ma kluczowe znaczenie. Gdy urzędnicy najwyższych szczebli są skorumpowani, agencja może być jedyną instytucja, która może doprowadzić do postępowania sądowego. Gdy system wymiaru sprawiedliwości funkcjonuje właściwie, mandat oskarżycielski jest zbędny, ponadto wykonywanie funkcji oskarżycielskich przez agencje wymaga dodatkowych zabezpieczeń przed ewentualnymi nadużyciami. Agencja powinna jednak zachować prawo do przedstawiania ujawnionych przypadków korupcyjnych oskarżycielom.

Oprócz typowych przestępstw korupcyjnych, działania agencji obejmują także przestępstwa przeciwko obrotowi gospodarczemu, finansowaniu partii politycznych, obowiązkom podatkowym i rozliczeniom z tytułu dotacji i subwencji, przyznawania koncesji, zezwoleń lub zwolnień podatkowych.

\subsection{Funkcja analityczno-informacyjna}

Cechą kompleksowego podejścia do walki z korupcją jest prowadzenie działalności analitycznej dotyczącej zjawisk występujących w obszarze właściwości agencji oraz informacyjnej ${ }^{52}$, polegającej na przedstawianiu wyników analiz odpowiednim organom i instytucjom. Funkcje: instrukcyjna, doradcza, wspierająca rządowe programy i publiczne instytucje wprowadzające zmiany praktyk i procedur, łącznie $z$ ewentualną propozycją zmian legislacyjnych, są wykonywane przez agencje (Australia, Botswana, Indonezja, Malezja, Korea, Tajlandia). W Indonezji CEC ma szeroki mandat $\mathrm{w}$ zakresie monitoringu rządowych przedsięwzięć. Tanzańskie PCCB przeprowadza badania procedur i rozwiązań prawnych, współpracuje z różnymi instytucjami wykrywając luki prawne sprzyjające zachowaniom korupcyjnym. Prowadzi również badania nad metodami zwalczania korupcji w innych państwach. Na Łotwie CPCB i SIS na Litwie są upoważnione do przeprowadzania analizy obowiązujących przepisów

51 A. Doig, D. Watt, R. Williams, Measuring 'success'..., s. 21.

52 J. Johnson, H. Mathisen, H. Hechler, L. de Sousa, How to monitor and evaluate anti-corruption agencies: Guidelines for agencies, donors, and evaluators, Chr. Michelsen Institute, U4 Issue 2011, nr 8, www.u4.no/publications [dostęp: 15 czerwca 2015 r.], s. 27. 
i propozycji poprawek. W myśl ustawy także polskie CBA prowadzi działalność analityczną dotyczącą zjawisk występujących w obszarze właściwości Biura oraz przedstawia w tym zakresie informacje Prezesowi Rady Ministrów, Prezydentowi Rzeczypospolitej Polskiej oraz Sejmowi ${ }^{53}$.

Międzynarodowe organizacje, współdziałające z organami krajowymi i społeczeństwem, również wnoszą duży wkład w działania prewencyjne. Prezydent Nigerii, Olusegun Obasanjo po wygranych wyborach w 1999 r. zwrócił się do wielu międzynarodowych organizacji, w tym Transparency International, o pomoc $\mathrm{w}$ walce $\mathrm{z}$ korupcją. Na tej podstawie zostały opracowane antykorupcyjne strategie rządowe i instytucjonalne, które są obecnie testowane ${ }^{54}$. Antykorupcyjne agencje w Hong Kongu, Chinach, Korei, Filipinach, Singapurze współpracują z podobnymi organizacjami z innych państw, dokonując wymiany doświadczeń i informacji ${ }^{55}$. Podobnie w Malezji przeprowadzane są specjalistyczne kursy z zakresu technik śledczych, gromadzenia dowodów, prewencji i dowodzenia. Cześć personelu wiedzę w tym zakresie uzyskała podczas kursów przeprowadzanych w Wielkiej Brytanii i Stanach Zjednoczonych.

\subsection{Działania prewencyjno-edukacyjne}

Działania organizacji antykorupcyjnych mogą obejmować też kreowanie „świadomości” funkcjonowania poza korupcją. Organizacje takie mogą wspierać wysiłki na rzecz poszanowania prawa i przyczyniać się do budowania „wolnego" środowiska biznesowego ${ }^{56}$.

Do skutecznej walki z korupcją niezbędne jest też wsparcie społeczne i edukacja zmierzająca do uświadomienia zagrożeń związanych z tym zjawiskiem i zachęcanie obywateli do działań w swoim interesie i dla dobra wspólnego. W Hong Kongu od początku zdawano sobie sprawę, iż media są potężnym i niezastąpionym partnerem $\mathrm{w}$ rozpowszechnianiu antykorupcyjnego przekazu ${ }^{57}$. Działalność ICAC przypadła na okres, kiedy tele-

${ }^{53}$ J. Becker, Polska w walce z korupcja, „Prawo Europejskie w praktyce” 2011, nr 2, s. 106.

${ }^{54}$ J. Pope, F. Vogel, Making Anticorruption Agencies..., s. 9.

55 Anti-Corruption Policies in Asia and the Pacific, The legal and Institutional Frameworks for Fighting Corruption in Twenty-one Asian and Pacific Countries, Asian Development Bank 2004, s. 39.

56 J. Pope, F. Vogel, Making Anticorruption Agencies..., s. 7.

${ }_{57}$ Hong Kong SAR jest znany z wolnej prasy. W 2000 roku wydawano około 60 dzienników i 700 periodyków. 
wizja docierała do szerokich kręgów społeczeństwa. Edukacja publiczna ICAC odbywa się w dwóch formach: szerokiego użycia mediów oraz kontaktów osobistych (face-to-face). Ponad 25-letni okres tych działań potwierdził efektywność wpajania kultury prawości. Wśród wielu innowacyjnych wysiłków realizowanych przez ICAC podejmowano produkcję seriali dokumentalnych opartych na autentycznych kazusach korupcyjnych. Seriale te są nadal cieszącymi się bardzo dużą oglądalnością programami telewizyjnymi ${ }^{58}$. Rewolucja cybernetyczna przyczyniła się do rozwoju interaktywnej komunikacji ze społeczeństwem. ICAC wprowadziła strony internetowe dla młodych internautów, wykorzystując interaktywne gry i informacje, w celu kształtowania właściwych postaw w zakresie zapobiegania korupcji.

Istotnym elementem walki z korupcją jest bezpośredni kontakt ze społeczeństwem, wyjaśnianie celów misji oraz uzyskiwanie dla nich poparcia społecznego. W Hong Kongu jest wykorzystywana strategiczna sieć regionalna urzędów, w celu utrzymywania bezpośredniego kontaktu z przedstawicielami różnych grup społeczeństwa. Urzędy utrzymują kontakty z lokalnymi liderami społecznymi i organizacjami podejmującymi działania na rzecz rozpowszechniania antykorupcyjnego przekazu. Organizowane są sesje publiczne i spotkania, wdrażane są programy szkoleniowe dla urzędników państwowych oraz osób działających w sektorze prywatnym. Realizowane są też programy edukacyjne, mające na celu rozwój antykorupcyjnej kultury wśród młodych ludzi i nowo przybyłych imigrantów. Utworzono centra umożliwiające składanie skarg. Prasowe biuro informacyjne było pierwszą jednostką ustanowioną przez ICAC. Działa ono jako pomost między ICAC a prasa, regularnie informując o prowadzonych operacjach, organizując konferencje i spotkania. W 1995 r. wspólnie z 6 głównymi izbami gospodarczymi utworzono Centrum Badań nad Etyką w Hong Kongu (Hong Kong Ethics Development Centre) w celu promocji etyki.

Społeczeństwo włączyło się aktywnie w realizację antykorupcyjnej strategii. Konsekwencja i skuteczność działań Niezależnej Komisji sprawiły, że cieszy się ona dużym społecznym zaufaniem. Nastawienie do samej korupcji również uległo zmianie: ciche przyzwolenie, zastąpiła otwarcie deklarowana negatywna postawa wobec korupcji.

${ }^{58}$ W serii pokazywano „straszne” konsekwencje korupcji w sposób realistyczny oraz profesjonalny i skuteczny sposób działania funkcjonariuszy. 
W Malezji zastosowano trójkierunkową strategię obejmującą informację, edukację i komunikację (tzw. I, E, C - Information, Education, Comunication). Wysiłki podejmowane w celu edukacji społecznej oparto na etyce i religii, eksponując takie czynnik jak: moralność, presja społeczna, poczucie własnej godności i lojalność. Wykorzystywano również programy telewizyjne, apelując o społeczną współpracę w walce z korupcją oraz ostrzegając o jej nieopłacalności ${ }^{59}$. Dzięki MACC przyjęto w 1993 r. przepisy dotyczące postępowania i karania urzędników publicznych, w 1994 r. zasady etyczne sędziów oraz nawiązano współpracę z organizacjami religijnymi. W 2000 r. rozpoczęto walkę z korupcją w sektorze prywatnym, angażując w tym celu specjalnie wyszkolony personel. Zadbano również o interesy i bezpieczeństwo świadków i informatorów ${ }^{60}$. Prowadzono poradnictwo w zakresie metod redukcji zachowań korupcyjnych ${ }^{61}$.

W literaturze przedmiotu podkreślono, że użytecznym narzędziem prewencyjnym jest też efektywny system monitoringu mienia, dochodów, pasywów, poziomu życia określonych decydentów oraz urzędników publicznych. Wydaje się, że w celu zwiększenia pozytywnego oddziaływania deklaracji majątkowych należy rozważyć stosowanie sądowej konfiskaty mienia lub nałożenia grzywny w przypadku podania nieprawdziwych informacji ${ }^{62}$. NCCC w Tajlandii prowadzi szeroką działalność w tym zakresie. Podobne działania może podejmować CPCB na Łotwie i CBA w Polsce.

\section{System kontroli}

Systemy kontroli i ponoszenia odpowiedzialności są zróżnicowane, w zależności od pełnionych zadań i sposobu usytuowania w aparacie państwa. Najbardziej charakterystyczną, modelową kontrolę prowadzi ICAC w Hong Kongu. Agencja przedkłada regularnie raporty dotyczące przeprowadzanych dochodzeń i dokonanych konfiskat mienia. Wyso-

${ }^{59}$ Nagrania prezentowały scenę dzwoniącego dzwonu w więzieniu, jako alegorię groźby kary, oraz scenę aresztu dokonywaną przed rodzina, jako alegorię wstydu.

${ }^{60}$ Anti-Corruption Guidance, Japan International Cooperation Agency, 2014, s. 15, www.jica.go.jp/english/index.html [dostęp: 15 czerwca 2015 r.].

${ }_{61}$ The Global Programme against Corruption..., s. 185 i n.

${ }^{62}$ J. Pope, Rzetelność życia publicznego..., s. 102. 
ki poziom działalności zapewniają komitety nadzorcze, w skład których wchodzą reprezentanci społeczeństwa. Komitety przedstawiają raporty z działalności ICAC Szefowi Egzekutywy Specjalnego Regionu Administracyjnego Hong Kongu ${ }^{63}$. Raporty te są publikowane i rozpowszechniane za pomocą Internetu. Każdy z komitetów odpowiada za kontrolę odpowiedniego departamentu. Komitet Operacyjny kontroluje bieżące dochodzenia, sprawy trwające dłużej niż 12 miesięcy, przypadki stosowania aresztowania przekraczającego 6 miesięcy, a także dokonywane przeszukania. Komitet pełni funkcję nadzorczą i doradczą - żadna sprawa nie może być umorzona bez jego zgody. Pozostałe komitety podejmują działania na rzecz zwiększenia społecznej świadomości w zakresie kosztów korupcji i środków podejmowanych w celu jej zwalczania. Doradczy Komitet Prewencji otrzymuje raporty dotyczące kosztów korupcji w sektorze prywatnym. Działalność tego departamentu wspiera departament stosunków społecznych (Citizen Advisory Committee - CAC - on Community Relations), odpowiadający za przeprowadzanie kampanii społecznych ${ }^{64}$. Kolejnym mechanizmem monitorującym jest Komitet Zażaleń, który otrzymuje, monitoruje i przegląda wszystkie skargi przeciw ICAC.

W Tanzanii działalność PCB jest monitorowana przez Komitet Kontroli i Oceny (Committee for Control and Evaluation - CCE) oraz Komitet Dyrektorów. Struktura Komitetu nie gwarantuje jednak niezależnego monitoringu. Komitet składa się z sekretarza urzędu prezydenta, dyrektora generalnego PCB oraz dyrektora generalnego Tanzańskiego Systemu Wywiadowczego i Bezpieczeństwa, zaś Komitet Dyrektorów tworzą dyrektor generalny PCCB i dyrektorzy PCCB.

W modelu dochodzeniowym charakterystycznym dla Singapuru mechanizmy kontrolne są mniej przejrzyste niż w przypadku Hong Kongu. CPIB przedstawia raporty Antykorupcyjnemu Komitetowi Doradczemu (Anti-Corruption Advisory Committee), który odpowiada przed Prezydentem. Brak jest systemu kontrolnego i wielofunkcyjnego systemu składania raportów istniejącego w Hong Kongu ${ }^{65}$. Kontrola nad CBA w Polsce obejmuje merytoryczną kontrolę prokuratora i sądu, kontrolę parlamentarną prowadzoną przez komisje do spraw służb specjalnych oraz składanie

${ }^{63}$ F. Anechiarico, Protecting integrity at the local level: the role of anticorruption and public management networks, "Crime, Law \& Social Change” 2010, nr 53, s. 85.

${ }^{64}$ J. R. Heilbrunn, Anti-Corruption Commissions..., s. 5.

${ }^{65}$ J. R. Heilbrunn, Anti-Corruption Commissions..., s. 7. 
corocznych sprawozdań przez Szefa CBA przed Sejmem na plenarnym posiedzeniu ${ }^{66}$.

$\mathrm{W}$ modelu parlamentarnym przyjętym w ICAC w Australii kontrola zagwarantowana jest przez obowiązek składania corocznych raportów oraz przeprowadzania wewnętrznych i zewnętrznych audytów. ICAC pozostaje pod kontrolą dwóch komisji: 1) Komisji Parlamentarnej (Parliament Joint Committee) składającej się z 11 członków Parlamentu, która nadzoruje i rewiduje działalność agencji, odpowiada za skargi obywatelskie kierowane do Rzecznika Praw Obywatelskich i Parlamentu oraz 2) Komitetu Rewizyjnego (Operations Review Committee - ORC) składającego się z 8 członków, który odpowiada za ogólną działalność jako agencji rządowej oraz pełni rolę doradczą $\mathrm{w}$ zakresie prowadzenia dochodzeń ${ }^{67}$. Pozostawienie sprawy bez rozpoznania wymaga konsultacji z ORC.

Inne państwa zdecydowały się na kontrolę niekolegialnych instytucji np. Prezydenta lub premiera. Należy jednak pamiętać, że agencje nie wypełniają swoich funkcji, jeśli są poddane politycznemu naciskowi i używane jako broń przeciw rządowym opozycjonistom ${ }^{68}$. Efektywna kontrola wymaga dodatkowego zewnętrznego narzędzia osłabiającego bezpośredni wpływ rządowy oraz „wertykalnej odpowiedzialności” jako elementu koniecznego, uzupełniającego „odpowiedzialność horyzontalną” prowadzoną przez inne organy państwa ${ }^{69}$.

\section{Uwagi końcowe}

Z politycznego punktu widzenia tworzenie wyspecjalizowanych instytucji jest sygnałem, że rząd jest zaangażowany $\mathrm{w}$ walkę z korupcją. W większości przypadków jednak, jeśli istniejący system jest w stanie poradzić sobie z problemem korupcji, wady stworzonej instytucji mogą przewyższyć zalety. Takie czynniki jak: specjalizacja, ekspertyzy lub na-

${ }^{66}$ M. Kamiński., Struktury, zadania i sposób funkcjonowania agencji antykorupcyjnych, Fundacja im. Stefana Batorego, Warszawa 2006, s. 14.

${ }^{67}$ J. R. Heilbrunn, Anti-Corruption Commissions..., s. 9.

68 J. Pope, F. Vogel, Making Anticorruption Agencies..., s. 8.

69 A. Keith, Invigorating Ghana's lagging anticorruption agenda: Instruments for enhanced civic involvement, "Ghana Center for Democratic Development (CDD-GHANA)" 2005, vol. 7, nr 2, s. 2. 
wet konieczny stopień niezależności można uzyskać przez ustanowienie lub restrukturyzację odpowiednich jednostek wewnątrz już istniejących organów. W państwach, które nie ustanowiły odrębnych agencji i działają za pomocą już istniejących, koordynacja jest jednym z głównych problemów wymagających specjalnych rozwiązań instytucjonalnych. W każdym przypadku ważne jest zapewnienie prostych i przejrzystych uregulowań prawnych i systemów postępowania. Zbyt złożona struktura na ogół nie spełnia dobrze funkcji prewencyjnej. Potrzebny jest również pewien okres na wdrożenie przyjętych rozwiązań i zapewnienie ich odpowiedniego funkcjonowania.

Agencje nie zawsze są skutecznym instrumentem do walki z korup${ } j a^{70}$. Największe osiągnięcia mają agencje z państw azjatyckich. Jednak zmniejszenie skali zjawiska korupcji w tych państwach nie było wyłączną zasługą utworzenia agencji ${ }^{71}$. Istotną rolę odegrało wiele innych czynników, m. in. kompleksowe podejście do problemu ${ }^{72}$. Trójkierunkowa strategia: wykrywanie, zapobieganie i edukacja społeczna umożliwiły im podejmowanie problemu korupcji u źródła. W ostatnim pięćdziesięcioleciu w Azji, Singapur i Hong Kong wykazały polityczną wolę walki z korupcją i odniosły spektakularne sukcesy. Należy jednak zauważyć, że „polityczna wola" nie gwarantuje jeszcze sukcesu. Do najistotniejszych czynników należy zapewnienie: 1 . odpowiedniej niezależności, umożliwiającej wykonywanie funkcji w sposób efektywny i bez oddziaływania niedozwolonych wpływów, 2. niezbędnych środków materialnych, 3. wyspecjalizowanego personelu oraz 4. szkoleń takiego personelu, w zakresie, w jakim będzie to wymagane do pełnienia ich funkcji (tak też art. 6 ust 2 Konwencji ONZ przeciw korupcji). Ważne też jest, by wszelkie specjalne uprawnienia nadawane agencjom były zgodne $\mathrm{z}$ międzynarodowymi normami praw człowieka, a sama agencja powinna działać zgodnie z prawem i być odpowiedzialna przed sądem ${ }^{73}$.

${ }^{70}$ F. Anechiarico, Protecting integrity..., s. 80, zob. też United Nations Development Programme (UNDP), Global Anti-Corruption Initiative (GAIN) 2014-2017, New York 2014, s. 17, www.undp.org [dostęp: 15 czerwca 2015 r.].

${ }^{71}$ Por. Ł. Goczek, Mniej państwa. Mniej korupcji, "Gazeta Wyborcza” z dnia 13 stycznia 2006, nr 12/01.

72 Report from the Commission to the Council and the European Parliament, EU Anti-Corruption Report, COM (2014) 38 final, Brussels 2014, s. 13, www.ec.europa.eu [dostęp: 15 czerwca 2015 r.].

${ }^{73}$ J. Pope, Rzetelność życia publicznego..., s. 200. 
Odpowiednią niezależność tym instytucjom zapewnia ustalenie takiej procedury mianowania personelu, która minimalizuje ewentualne nadużycia ${ }^{74}$. Jeśli egzekutywa lub partia rządząca będzie miała pełną swobodę $\mathrm{w}$ dokonywaniu wyboru kierownictwa agencji, to może to negatywnie wpłynąć na efektywność działań agencji i zaufanie dla niej ze strony społeczeństwa. Usuwanie ze stanowiska w agencji nie powinno być pozostawione dyskrecjonalnemu uznaniu władzy, lecz następować zgodnie z przyjętymi i otwartymi procedurami, tylko w przypadku niekompetencji lub nadużyćc ${ }^{75}$. Praktyka działania agencji wskazuje na ich różny poziom autonomii. W przypadku agencji odnoszących największe sukcesy nie była to pełna niezależność - Botswana (prezydent), Hong Kong (szef rządu), Singapur (premier). Istotne znaczenie ma odpowiedni system kontroli i równowagi (check and balance), zapewniający bezstronne funkcjonowanie agencji bez nacisków i manipulacji.

Skuteczna walka oznacza konieczność traktowania korupcji jako przestępstwa wysokiego ryzyka. Istotne znaczenie ma zatem nieuchronność poniesienia kary przez sprawców przestępstw - bez względu na ich pozycję (zawodową, społeczną) i znajomości.

Efektywne działania wymagają zaangażowania wielu instytucji krajowych (od których w dużej mierze uzależniony jest efekt końcowy) działalność agencji powinna być zintegrowana i skoordynowana z pracą policji, administracji i prokuratury ${ }^{76}$. Do prawidłowego funkcjonowania agencji przyczynia się też ścisła współpraca nie tylko z organami administracji rządowej, samorządowej, ale także z organizacjami pozarządowymi. Istotne znaczenie ma też prowadzenie badań, wymiana informacji i doświadczeń między organizacjami sektora publicznego, zarówno na poziomie krajowym, jak i międzynarodowym oraz społeczeństwem i sektorem prywatnym.

Słowa kluczowe: antykorupcyjna agencja, antykorupcyjne biuro, antykorupcyjna komisja, korupcja

${ }^{74}$ E. P. Bolongaita, An exception to the rule? Why Indonesia's Anti-Corruption Commission succeeds where others don't - a comparison with the Philippines' Ombudsman, Chr. Michelsen Institute, U4 Issue 2010, nr 4, www.u4.no/publications [dostęp: 15 czerwca 2015 r.], s. 17.

75 J. Pope, Rzetelność życia publicznego..., s. 97.

${ }^{76}$ Explanatory Report on the Criminal Law Convention on Corruption, www.coe.int [dostęp: 13 czerwca 2015 r.], pkt 96. 


\section{Bibliografia}

\section{Konsultowane strony internetowe:}

Centralne Biuro Antykorupcyjne: www.cba.gov.pl.

Antykorupcyjna Agencja w Malezji: www.bpr.gov.my.

Biuro Prewencji Korupcji w Tanzanii: www.tanzania.go.tz/pcb.

Biuro Zwalczania i Zapobiegania Korupcji na Łotwie: www.knab.gov.lv/en.

Biuro ds. Ścigania Praktyk Korupcyjnych w Singapurze: www.cpib.gov.sg.

Komisja Zwalczania Korupcji w Indonezji: www.kpk.go.id.

Koreańska Niezależna Komisja Przeciw Korupcji: www.kicac.go.kr.

Niezależna Komisja Przeciw Korupcji w Hong Kongu: www.icac.org.hk/eng/ main.

Niezależna Komisja Przeciw Korupcji w Australii: www.icac.nsw.gov.au.

Niezależna Komisja ds. Praktyk Korupcyjnych i innych Przestępstw w Nigerii: www.icpcnigeria.com.

Dyrektoriat ds. Korupcji i Przestępczości Ekonomicznej: www.gov.bw/government/directorate_on_corruption_and_economic_crime.html

Specjalna Służba Dochodzeniowa na Litwie: www.stt.lt/?lang=en.

Państwowa Komisja ds. Walki z Korupcją w Tajlandii: www.nccc.thaigov.net/ nccc/eng.php.

Transparency International Corruption Perception Index: www.transparency.org/research/cpi.

\section{Opracowania książkowe i artykuły:}

Anechiarico F., Protecting integrity at the local level: the role of anticorruption and public management networks, "Crime, Law \& Social Change” 2010, nr 53.

Becker J., Polska w walce z korupcja, Prawo Europejskie w praktyce" 2011, nr 2. Bolongaita P. E., An exception to the rule? Why Indonesia's Anti-Corruption Commission succeeds where others don't - a comparison with the Philippines' Ombudsman, Chr. Michelsen Institute, Chr. Michelsen Institute, U4 Issue 2010, nr 4, www.u4.no/publications.

Carr I., Corruption, the Southern Africa Development Community Anti-corruption Protocol and the principal-agent-client model, "International Journal of Law in Context" 2009, nr (5) 2.

Coonjohn J. J., A primer on Models and Strategies 2011 for Anti-Corruption Agencies. Preparing Afghanistan for Anti-Corruption Reform, www.jjcoonjohn. com.

Doig A., Watt D., Williams R., Measuring 'success' in five African Anti-Corruption Commissions - the casus of Ghana, Malawi, Tanzania, Uganda E Zambia., U4 reports, May 2005.

Goczek Ł., Mniej państwa. Mniej korupcji", Gazeta Wyborcza 12/01/2006. 
Harding A., Nicholson P., New Courts in Asia, "Asian Journal of Criminology" 2012, v. 7, nr. 2.

Heilbrunn J. R., Anti-Corruption Commissions: Panacea or Real Medicine to Fight Corruption?, World Bank Institute 2004.

Jones J., India versus tje United Nations: The Central Vigilance Commission Act Does Not Satisfy The U.N. Convention Against Corruption, „Emory International Law Review" 2008, nr 22.

Johnson J., Mathisen H., Hechler H., Sousa L. de, How to monitor and evaluate anti-corruption agencies: Guidelines for agencies, donors, and evaluators, Chr. Michelsen Institute, U4 Issue 2011, nr 8, www.u4.no/publications.

Kamiński M., Struktury, zadania i sposób funkcjonowania agencji antykorupcyjnych. Fundacja im. Stefana Batorego, Warszawa 2006.

Keith A., Invigorating Ghana's lagging anticorruption agenda: Instruments for enhanced civic involvement., Ghana Center for Democratic Development (CDD-GHANA), May 2005, Vol. 7, Number 2.

Pope J., Vogel F., Making Anticorruption Agencies More Effective, Finance\&Development, 2000, vol. 37, nr 2.

Pope J., Confronting corruption: the elements of a national integrity system, Berlin 2000.

Pope J., Rzetelność życia publicznego. Metody zapobiegania korupcji, \{tłum. M. Pertyński\}, Warszawa 1999.

Quah J. S. T., Curbing Asian Corruption: An Impossible Dream?, Current History, April 2006.

Quah J.S.T., Anti-Corruption Agencies in Four Asian Countries: A Comparative Analysis, "International Public Management Review" 2007, vol. 8, nr 2.

Quah J. S. T., Defying institutional Failure: learning from the experiences of anti-corruption agencies in four Asian countries, "Crime, Law \& Social Change" 2010.

Schütte S. A., Butt S., Assessing judical performance in Indonesia: the court for corruption crimes, „Crime Law \& Social Change” 2014, v. 62, nr 5.

\section{Opracowania instytucji i organizacji międzynarodowych:}

Anti-Corruption Guidance, Japan International Cooperation Agency 2014, www.jica.go.jp/english/index.html.

Anti-Corruption Policies in Asia and the Pacific - The legal and Institutional Frameworks for Fighting Corruption In Twenty-one Asian and Pacific Countries, Asian Development Bank 2004.

Explanatory Report on the Criminal Law Convention on Corruption, www. coe.int.

Instytucje antykorupcyjne w wybranych państwach świata, Centralne Biuro Antykorupcyjne, Warszawa 2010, www.cba.gov.pl. 
Institutional Arrangements to Combat Corruption. A Comparative Study. United Nations Development Programme 2005.

Report from the Commission to the Council and the European Parliament, EU Anti-Corruption Report, COM (2014) 38 final, Brussels 2014, www. ec.europa.eu.

Struktury, zadania i sposób funkcjonowania agencji antykorupcyjnych. Fundacja im. Stefana Batorego Warszawa, 12 maja 2006.

The Global Programme against Corruption. UN Anti-Corruption Toolkit, 3nd Edition, UNODC Vienna, September 2004.

Transparency International Corruption Perceptions Index 2014: Results: www.transparency.org/cpi2014/results.

Transparency International Corruption Perceptions Index 2007: Results: www.transparency.org/research/cpi/cpi_2007.

United Nations Development Programme (UNDP), Global Anti-Corruption Initiative (GAIN) 2014-2017, New York 2014, www.und p.org.

Uzasadnienie projektu ustawy o Centralnym Biurze Antykorupcyjnym, Sejm RP V kadencji, Nr druku 275.

\section{ANTI-CORRUPTION AGENCIES IN THE WORLD - LEGAL AND ORGANIZATIONAL PROBLEMS}

\section{$\mathrm{S} \mathbf{u} \mathbf{m} \mathbf{m}$ a $\mathbf{r} \mathbf{y}$}

Creating independent agencies, offices or anti-corruption commissions becomes a common practice used by the states aiming to a comprehensive fight against corruption. This kind of institutional arrangements introduced in many countries in Europe, Africa, Asia and America, also in Poland created an anti-corruption agency called the Central Anticorruption Bureau. The need for creation of anti-corruption agencies also highlighted at international level. A number of international documents on preventing and combating corruption contain a requirement to create the appropriate agency or unit whose main purpose is to prevent and combat corruption.

The paper reviews the institutional solutions adopted in different countries, with special emphasis on the leading anti-corruption agencies in the world (in Hong Kong, Singapore and Australia) and those countries, where according to the Corruption Perceptron Index, which estimates the level of corruption in the country, have not reached the highest results, to demonstrate that such institutions per se do not eliminate corruption. Many other factors play more important role, like, three-dimensional strategy: detection, prevention and public education.

Keywords: Anti-corruption agency, anti-corruption bureau, anti-corruption commission, corruption 


\title{
АНТИКОРРУПЦИОННЫЕ АГЕНТСТВА В МИРЕ - ПРАВОВЫЕ И ОРГАНИЗАЦИОННЫЕ ПРОБЛЕМЫ
}

\author{
P e 3 го м
}

Создание независимых агентств, офисов или комиссии по борьбе с коррупцией становится общепринятой практикой, которая используется государством с целью борьбы с коррупцией. Такого рода институциональные механизмы введены во многих странах Европы, Африки, Азии и Америки, а также в Польше создано агентство по борьбе с коррупцией - Центрадьное антикоррупционное бюро. Необходимости создания антикоррупционных органов также уделено особое внимание на международном уровне. Ряд конвенций по предотвращению и борьбе с коррупцией требует, чтобы стороны создавали соответствующий орган или органы, основная цель которых заключается в предотвращении и борьбе с коррупцией.

В исследовании рассматриваются институциональные решения, принятые в разных странах, уделяя при этом особое внимание на ведущие мировое агенства по борьбе с коррупцией (в Гонконге, Сингапуре и Австралии) и те страны, которые, согласно индексу восприятия коррупции, оценивая общий уровень коррупции в стране, не достигли наивысших результатов, чтобы показать, что такие агентства как таковые не ликвидируют коррупцию. Важную роль играют многие другие факторы, в частности трехмерная стратегия: выявление, предотвращение и социальное образование.

Ключевые слова: антикоррупционное агентство, бюро, комиссия, коррупция 